\title{
The Investment Account Holders Disclosure Level in the Annual Reports of Islamic Banks: Construction of IAHs Disclosure Index
}

\author{
Raoudha Saidani ${ }^{1 *}$, Neila Boulila Taktak** and Khaled Hussainey*** \\ *, **Institute of Advanced Business Studies (IHEC Carthage), University of Carthage, \\ Tunisia \\ ***Portsmouth Business School, Portsmouth University, UK
}

\begin{abstract}
This paper aims to measure the IAHs disclosure level in the annual reports of Islamic banks. To do this, we develop a specific IAHs disclosure index based on Accounting and Auditing Organization for Islamic Financial Institutions (AAOIFI) standards. We use manual content analysis of 49 fullfledged Islamic banks' annual reports over the period 2011-2015 across 10 countries. The findings of this study show that the overall level of IAHs disclosure is 28 per cent. Indeed, the sampled Islamic banks provide fewer disclosures related to IAHs. The present study contributes to enrich the knowledge of Islamic accounting literature by exploring directly the IAHs disclosure level in the annual reports of Islamic banks via self-constructed IAHs disclosure index based on AAOIFI accounting standards. It can help regulators in different countries to understand and strengthen the IAHs disclosure practices in Islamic banks by imposing AAOIFI disclosure requirements in terms of IAHs reporting.
\end{abstract}

Keywords: Investment Account Holders, Islamic banks, IAHs disclosure index, AAOIFI accounting standards, manual content analysis.

JEL classifications: G20, M41

\footnotetext{
${ }^{1}$ Corresponding author: saidaniraoudha@hotmail.fr
} 


\section{Introduction}

The global financial crisis has led to a crisis in investors' confidence towards the conventional banking system and increased interest to the Islamic finance industry, in particular Islamic banks as they recognized by their resilience during the financial crisis. Thus, transparent disclosures and relevant information stimulate the interests of investors in achieving better allocation of their funds and eventually to a better decision making. According to the IMF Working Paper of November (2002, p. 12) "Information disclosure is more important in an Islamic environment than it is in a conventional system because of the profit and loss sharing principle and the implied lack of protection for investment depositors which are at the core of Islamic banking”. Investment Account Holders (IAHs) represent the main source of financing for Islamic banks and yet, they are not allowed to interfere in the management of their funds. Indeed, IAHs are not authorized neither to designate the board of directors, nor the members of Sharia Board and the external auditors (Al-Baluchi, 2006). Thus, disclosure of relevant information for IAHs in the annual reports of Islamic banks is very important, because it contributes to reducing information asymmetry and to protect the IAHs' rights.

It is in this sense that Islamic banks are expected to provide more relevant disclosures in their annual reports that the IAHs find useful. Previous studies have mainly focused on CSR disclosure, corporate governance disclosure, Sharia governance and compliance with AAOIFI Standards levels in Islamic banks (e.g., Maali et al., 2006; Haniffa and Hudaib, 2007; Hassan and Harahap, 2010; Farook et al., 2011; Ullah, 2013; Farag et al., 2014; Abdullah et al., 2015; El-Halaby and Hussainey, 2015; El-Halaby et al., 2017).

There are very few studies that include IAHs as one of the categories of their disclosure indices, such as corporate governance disclosure indices in Islamic banks (e.g., Abdullah et al., 2015; Srairi, 2015; Sulaiman et al. 2015). However, to the best of our knowledge, there 
have been no prior studies which investigate directly the level of IAHs disclosure in Islamic banks' annual reports through the development of a specific IAHs disclosure index. Therefore, the present study contributes to fill this gap in existing Islamic accounting literature. According to Sarea and Hanefah (2013), the AAOIFI accounting standards may reflect the unique characteristics of Islamic banks. Since the IAHs are considered unique to Islamic banks, we developed a specific IAHs disclosure index based mainly on AAOIFI IAHs reporting standards to measure the IAHs disclosure level in the annual reports of a sample of 49 full-fledged Islamic banks over the period 2011-2015. This is the first study which investigates directly the extent of IAHs disclosure practices in the annual reports of Islamic banks using a self-constructed IAHs disclosure index based on AAOIFI accounting standards. Using manual content analysis, the findings indicate that the sampled Islamic banks provide poor disclosures in relation to IAHs (28\%) as they disclose below $50 \%$ of the AAOIFI IAHs disclosure requirements. This study could enrich the existing literature on corporate disclosure and transparency in Islamic banks. It can also help regulators bodies in different countries to improve IAHs disclosure practices in Islamic banks by imposing the application of AAOIFI accounting standards.

The remainder of this paper is organized as follows. Section 2 presents the role of IAHs in Islamic banks. Section 3 provides the relevant literature review. Section 4 describes the research methodology. Section 5 presents and discusses the results. The robustness test is covered in Section 6 and finally Section 7 concludes the study.

\section{The role of IAHs in Islamic banks}

Islamic banks, like other financial institutions, need deposits to ensure their survival and functioning. According to AAOIFI Conceptual Framework (AAOIFI, 2010, p. 15) "an 
asset is a resource controlled by an $\mathrm{IFI}^{2}$, whether financed by owners or its investment account holders, as a result of a past transactions, event or condition which provides the IFI an enforceable right over the resource and gives it an economic benefit, present or future". This means that Islamic banks hold capital mainly from two categories of stakeholders, namely Shareholders and Investment Account Holders.

The investment accounts ${ }^{3}$ are unique to Islamic financial institutions and defined as "funds received for the purpose of investment on a profit sharing or participation basis under Mudaraba arrangements" (AAOIFI, 2010, p. 15). The deposits are mostly collected from the IAHs which represent the main source of funds for Islamic banks compared to shareholders' funds (Al-Deehani et al., 1999; Al-Baluchi, 2006; Archer and Karim, 2009; Archer et al., 2010; AlShattarat and Atmeh, 2016). The investment account holders provide economic resources, usually cash, to the IFI for investment purposes with the expectation of receiving profits attributable after paying the IFI a share of the profit and a fee where relevant (AAOIFI, 2010, p. 15).

Furthermore, there are two types of investment accounts, namely unrestricted investment accounts and restricted investment accounts. The unrestricted investment account is considered by AAOIFI as on-balance sheet account where the investor fully authorizes the bank to invest the funds without restrictions as to where, how and what purpose the funds should be invested, given that funds in unrestricted investment accounts are commingled with the bank's own funds, whereas restricted investment account represent an off balance sheet account where the investor restricts the manner as to where, how and for what purpose the funds are to be invested (Abdul Rahman, 2010). Unrestricted investment accounts are often the most common accounts in Islamic banks. According to Van

\footnotetext{
${ }^{2}$ Islamic Financial Institution (IFI)

${ }^{3}$ Investment Accounts are also known under other names including Profit Sharing Investment Accounts (PSIAs), Profit Loss Sharing deposits, Mudaraba Investment Accounts or Mudaraba funds.
} 
Greuning and Iqbal (2008, p.195) "Unrestricted IAHs are the third and the most important category of Islamic bank accounts. They constitute the majority of deposits and are a characteristic feature of Islamic finance, posing distinctive challenges..." The authors added that "Unrestricted account holders usually enter into a mudarabah contract with the Islamic bank, in which the Islamic bank manages their funds and pays a share of returns according to a predetermined profit- and loss-sharing ratio".

Accordingly, IAHs funds can be classified neither as liability nor as equity. Thus, they are presented as a separate item between liabilities and owners' equity in the statement of financial position of Islamic banks that adopt AAOIFI standards, whereas Islamic banks that adopt IAS/IFRS standards classified these funds as liabilities (AlShattarat and Atmeh, 2016; Sori, 2017).

Despite the status of IAHs as major stakeholders, they are not allowed to interfere in the management of their funds. Unlike the shareholders, IAHs have no voting rights and have not even the right of equal access to relevant information. Indeed, IAHs are allowed to designate neither the board members, nor the members of Sharia Board and the external auditors. In the last resort, they can withdraw their funds (Archer et al., 1998; Karim, 2001; Al-Baluchi, 2006). However, IAHs withdrawals are not beneficial to Islamic banks (i.e. Shareholders). Hence, the latter has an incentive to maintain a higher level of IAH investment as a source of profits via the mudarib share. Nevertheless, IAHs should be protected from the risk of volatility in their returns at the expense of shareholders. Thus, the latter should sacrifice a part or his entire mudarib share of profits to smooth the returns paid to IAHs. This is known as displaced commercial risk and Islamic banks do their best to mitigate this risk through the use of two types of reserves, namely profit equalization reserve and investment risk reserve (Archer and Karim, 1998; Archer et al., 2010). 
On the whole, IAHs have no representation on the board of directors, although they are of great importance as providers of funds to Islamic banks. Therefore, this category of stakeholders needs relevant information about the management of their funds in order to protect their rights and to reach better decision-making. This is why Islamic banks have to be transparent to their IAHs by disclosing essential information for them in their annual reports.

\section{Literature Review}

Despite the importance of the IAHs, there are very few disclosure studies in the Islamic banking industry that include IAHs as one of the categories of their disclosure indices and not as the overall disclosure index (e.g., Abdullah et al., 2015; Srairi, 2015; Sulaiman et al. 2015).

Al-Baluchi (2006) examined in his thesis a sample of 34 Islamic banks located in Bahrain, Qatar, Jordan and Sudan for the year 1997 (before implementation of AAOIFI Standards) and 2002 (after implementation of AAOIFI Standards) to explore the level of voluntary disclosure in the annual reports of Islamic banks. To measure the overall level of disclosure, he developed a voluntary disclosure index for the year 2002 based on AAOIFI Standards, which mainly involves FAS1 and FAS5, FAS6 and FAS 11, and consisting of 104 items classified into four groups, being "Disclosure of general corporate information", "Disclosure of Reports", "Disclosure of financial information in the financial statements" and "Disclosure of information in the notes to the financial statements". The findings showed that the average voluntary disclosure level was 44\%. In all, Al-Baluchi (2006) revealed that the level of voluntary disclosure increased after the implementation of AAOIFI Standards. 
Abdullah et al. (2015) explored the extent of voluntary corporate governance disclosure of 67 Islamic banks in the SEA and GCC regions for the year 2009. Thus, they constructed a disclosure index based on the OECD Principles of Corporate Governance (2004), the Basel Committee on Bank Supervision (2006) Report, the AAOIFI Standards (2010), the IFSB guidelines, other standards and previous studies on corporate governance disclosures. Then, the index included a total of 81 items classified into 13 disclosure categories. The findings revealed that the average level of voluntary corporate governance disclosure is $37.01 \%$ with a low level of $35.86 \%$ related to disclosure on "Equitable treatment of fund providers and other significant stakeholders".

Moreover, Sulaiman et al. (2015) examined a sample of 16 Islamic Financial Institutions (IFIs) in Malaysia to determine the disclosure quality of corporate governance in their annual reports for the year 2009. For this purpose, they developed a corporate governance disclosure index, as a proxy for disclosure quality, based on the BNM guidelines (2007), Governance standards issued by AAOIFI (2008) and IFSB guidelines (2006) and consisting of 123 items grouped into 14 dimensions. Using content analysis, they found a corporate governance disclosure level of $51.42 \%$. Their results also revealed that risk management committee disclosure is the most disclosed dimension of the disclosure index with a mean score of $85.16 \%$, whereas, customers/IAHs information is the least disclosed dimension with a mean score of $2.68 \%$.

More recently, Srairi (2015) focused on 27 Islamic banks located in 5 Arab Gulf countries to investigate the impact of corporate governance disclosure level on bank performance. To measure the corporate governance disclosure level, he developed a disclosure index that contains 63 items classified into six major governance categories, namely board structure, risk management, transparency and disclosure, audit committee, Sharia supervisory board and investment account holders. Indeed, these disclosure items and categories were 
selected based on prior studies and international benchmarks such as the OECD guidelines (2004), corporate governance codes in the GCC countries, corporate governance standards promulgated by AAOIFI and the IFSB framework. Subsequently, he analyzed the content of the annual reports over the period 2011-2013 and he revealed a corporate governance disclosure level of $54 \%$ with Sharia governance information being the highest mean disclosure category (71\%) and disclosures on IAHs being the lowest mean disclosure category $(37 \%)$ of corporate governance disclosure.

In the light of the above, it seems obvious that the disclosures on IAHs represented low levels of corporate governance disclosure. In addition, both Sulaiman et al. (2015) and Srairi (2015) revealed that IAHs, as governance disclosure category, were the less disclosed category of their corporate governance disclosure indices.

In reviewing the literature, it seems that previous studies were mainly focused on CSR disclosure, corporate governance disclosure, Sharia governance and compliance with AAOIFI Standards levels in Islamic banks. The findings of most of these studies indicated low levels of disclosures and they were far below authors' expectations. However, to the best of our knowledge, no studies have investigated directly the level of IAHs disclosure in the annual reports of Islamic banks via the construction of a specific IAHs disclosure index using AAOIFI standards. Therefore, the present study contributes to fill this gap in existing Islamic Accounting literature.

\section{Research methodology}

\subsection{Sample selection}

The aim of the present study is to measure the IAHs disclosure level in the annual reports of Islamic banks. Thus, we focused on secondary data which are the annual reports of 
Islamic banks. Indeed, the annual reports are considered as the only source in which essential IAHs information should be disclosed.

The sample consists of 49 full-fledged Islamic banks over the period 2011-2015 which involves 245 observations across 10 countries. Furthermore, the sampled Islamic banks were selected using the list of banks, which is presented in Islamic Banks and Financial Institution Information database called "IBISONLINE" (www.ibisonline.net). It should be noted that the selection of our sample was based primarily on the Islamic banks' annual reports which are available on their official websites for the period 2011-2015. However, to ensure the homogeneity of our sample, we excluded Islamic banks that publish only interim or financial statements. Further, we excluded a number of Islamic banks that do not found in the Internet Site because they are closed or merged.

The AAOIFI standards 2010 edition is used in the current study. It considered as the most recent available edition of AAOIFI standards. Therefore, it covered the sample period of the five most recent years (2011-2015) during the conduction of this study. This means that the year of beginning of the study is 2011 which is the year of application of the 2010 edition of the AAOIFI standards, while the year of 2015 is the year in which the last available annual report is found in the Islamic banks' websites during the conduction of the study.

\subsection{Construction of the IAHs Disclosure Index}

Self-constructed disclosure index as a measure of either level or quality of corporate disclosures has been well acknowledged in the accounting disclosure literature. It is used in a variety of corporate disclosure studies in general (for example, Cerf, 1961; Barrett, 1976; Cooke, 1989a; Botosan, 1997; Hassan, 2012; etc.) and disclosure studies in the Islamic banking industry in particular. Indeed, there are a number of studies that developed 
disclosure index through content analysis to evaluate the extent of disclosure within the annual reports of Islamic banks (e.g., Maali et al., 2006; Haniffa and Hudaib, 2007; Hassan and Harahap, 2010; Abdullah et al. , 2015; Sulaiman et al. , 2015; Srairi, 2015; El-Halaby and Hussainey, 2016; etc.). In this study, the level of IAHs disclosure corresponds to the level of disclosure of essential information oriented for IAHs in the annual reports of Islamic banks. Referring to these previous studies, it is also measured through the construction of a specific disclosure index. Thus, following Hussainey (2004), the construction of our disclosure index involves the following steps.

\subsubsection{Selecting the initial list of disclosure items}

As aforementioned, there is no prior study relating directly to the extent of IAHs disclosure in the annual reports of Islamic banks through the construction of a disclosure index based on AAOIFI Accounting standards. However, there are a number of studies that include IAHs as one of the disclosure categories of their disclosure indices (Abdullah et al., 2015; Srairi, 2015; Sulaiman et al., 2015). Then, the first list of disclosure items was developed based on reviewing the relevant disclosure literature, AAOIFI accounting standards (FAS 1, FAS2, FAS 3, FAS4, FAS 5, FAS6, FAS 11 and GSIFI 6) ${ }^{4}$ and based on the current practice in Islamic banks (pilot study). Indeed, we carried out a pilot study, to refine the list of items, by scoring 35 annual reports of 7 Islamic banks across 7 different countries for a period of five years (2011-2015). We used manual content analysis to extract relevant items related to IAHs issues from the selected annual reports. Then, five disclosure categories and 61 items in the IAHs disclosure index, which could be observed in the annual reports of Islamic banks, were initially selected.

\footnotetext{
${ }^{4}$ See Appendix 2
} 


\subsubsection{Selecting the final list of disclosure items}

As noted by Hussainey (2004, p. 49) "Different methodologies are applied in the literature to select the final list of disclosure topics. These methodologies include: (1) sending out questionnaires to the users of financial reports, (2) conducting interviews or (3) relating to recommendations provided by the accounting profession and accounting standards". In this study, the initial list of disclosure items was reviewed by two professors in Accounting having knowledge in Islamic finance and two accounting professionals, who are working in the Islamic banking industry. Then, after discussing with them and as a result of their recommendations, we made some amendments to the disclosure index to enhance its validity. Overall, a disclosure item was retained in the disclosure index if it was disclosed by at least one Islamic bank (Al-Baluchi, 2006). Accordingly, the final list of disclosure items consists of 53 items classified into three disclosure categories namely: (1) Investment Account Holders (27 items), (2) Products (Murabaha, Mudaraba and Musharaka) (23 items) and (3) IAHs Risk Management (3 items) (see Appendix 1).

\subsubsection{Scoring of the IAHs disclosure index}

After developing the IAHs disclosure index and ensuring its validity, we proceeded to the weighting of the disclosure index. Indeed, an unweighted scoring approach is employed to examine the presence or absence of the IAHs disclosure items in the annual reports of Islamic banks. This method has been previously used by many researchers (e.g., Cooke, 1989b; Gray et al., 1995; Al-Baluchi, 2006; Haniffa and Hudaib, 2007; Abdullah et al., 2013; etc.). According to them, the main reasons for not giving weights to disclosure items are that each item of disclosure is equally important and to avoid subjectivity. Indeed, weighted approach reflects the perception rather than actual information needs of the users of financial information (Al-Baluchi, 2006). In addition, since our disclosure index was developed using the AAOIFI accounting standards, the latter does not mention in its 
regulation if there are more important items than others. Thus, the unweighted scoring approach is more suitable for this study. In any case, it has been shown previously that regardless of the approach adopted (weighted or unweighted), the results of the two approaches are similar (Inchausti, 1997).

The measure of IAHs disclosure level is obtained by analyzing the content of the annual reports of each Islamic bank and for each year. Then, by using a dichotomous approach, each item is given a score 1 if it is disclosed in the annual report and 0 if it is not disclosed and the disclosure index score of each bank was then calculated as follows:

$$
\text { D_IAHs }{ }_{\text {it }}=\sum_{i=1}^{N} \mathrm{Xji} / \mathrm{N}
$$

Where,

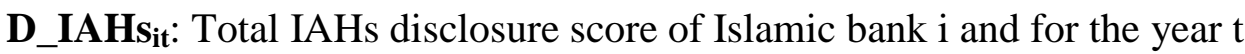

$\mathbf{N}$ : Total number of items in the IAHs disclosure index (53 items)

$\mathbf{X j i}$ : equal to 1 if the item $\mathrm{j}$ is disclosed in the annual report of the Islamic bank $\mathrm{i}$ and 0 if it is not disclosed.

Subsequently, to determine the total index of the whole sample, individual scores were added together and that total was then divided by the total number of items, which summarizes the overall extent of IAHs disclosure in a single number (Hussainey, 2004).

\subsection{Reliability of IAHs Disclosure measure}

Once the scoring method is assigned, we used manual content analysis to determine the extent of IAHs disclosure in the annual reports of all the sampled Islamic banks. According to Hussainey (2004:53) “Traditional content analysis via manual reading is generally more effective than the computerized analysis in identifying certain themes in the texts". Indeed, it permits the quantitative assessment of achieved reliability (Beattie et al., 2004). However, this approach is not without criticism. Thus, it is extremely time-consuming 
process, specifically with the presence of large volumes of textual data. Furthermore, human coders could make mistakes during their analyses. They could overlook some text of relevant content, potentially affecting the validity of the measure (Hussainey, 2004). Weber (1990:12) states that "To make valid inferences from the text, it is important that the classification procedure be reliable in the sense of being consistent: Different people should code the same text in the same way". It is then necessary to assess the reliability of the IAHs Disclosure measure. Reliability is defined by Neuendorf $(2002$, p. 112) as "the extent to which a measuring procedure yields the same results on repeated trials".

According to Krippendorff (2004), there are three types of reliability for content analysis, which are stability, reproducibility and accuracy. He pointed out that reproducibility, which is defined as the extent to which different coders produce the same results when coding the same content, is the strongest measure of reliability.

Therefore, after completing the content analysis process, we designated an independent coder to review a sample of four Islamic banks for a period of 3 years (2013-2015), which represent a total of 12 randomly selected annual reports. First, we explained to the independent coder the purpose of our research and the disclosure categories and items included in the IAHs disclosure index. Second, we provided him some decision rules to replicate the coding process of the selected annual reports. Then, we compared the results obtained from the two coders (i.e. we compared both the total scores from the two coders) to ensure that the discrepancies between the coders are few, or that the discrepancies have been re-analyzed and the differences resolved (Milne and Adler, 1999).

In doing so, we used Krippendorff's alpha test, which is considered as the most appropriate measure of reliability in content analysis. Krippendorff (2004) required an alpha $\geq 0.800$ for acceptable level of inter-coder reliability with a minimum of 0.667 (Krippendorff, 2004). In this research, Krippendorff's alpha coefficient is 0.836 , which is widely 
acceptable since it exceeds the required minimum threshold of 0.667 and also above 0.800 . We can say then that we have achieved a satisfactory level of reliability of the IAHs Disclosure measure.

On the other hand, Botosan (1997) highlighted the importance to assess the validity of the disclosure index. For that, he suggested four analyses, which are the correlation among the components of disclosure index, Cronbach's coefficient alpha, the correlation between disclosure scores and firm characteristics identified in prior studies to be associated with the level of corporate disclosures, and the correlation between the disclosure scores and the AIMR-FAF disclosure scores (Hussainey, 2004).

Thus, to check the validity of our IAHs disclosure index, we perform the correlation analysis between the IAHs disclosure level and the different categories of IAHs disclosure index (IAHs, Products, and IAHs risk management). Botosan (1997) supposed that the components of the disclosure index have to be positively and significantly correlated with one another to ensure the validity of the disclosure index.

Table 1: Correlation among the components of IAHs disclosure index

\begin{tabular}{|c|c|c|c|c|}
\hline & IAHsdisclevel & IAHS & PRODUCTS & RISKMGT \\
\hline IAHsdisclevel & 1.0000 & & & \\
\hline$I A H S$ & $0.8888^{*}$ & 1.0000 & & \\
\hline PRODUCTS & $0.8379 *$ & $0.4992 *$ & 1.0000 & \\
\hline RISKMGT & $0.5533^{*}$ & $0.5569 *$ & $0.3013 *$ & 1.0000 \\
\hline
\end{tabular}

The table above shows that all the categories of IAHs disclosure index are positively and significantly correlated with the IAHs disclosure level. Thus, the IAHs disclosure index is validated. 


\section{Results and discussion}

In this section, we analyze and interpret the results of IAHs disclosure index of the sampled Islamic banks during the period between 2011 and 2015. Table 2 presents the descriptive statistics. It indicates that the average of overall IAHs disclosure level is $28 \%$. It means that the sample Islamic banks disclosed only $28 \%$ of the IAHs disclosure index, which is very low as they disclosed below $50 \%$ of the AAOIFI IAHs disclosure requirements. Then, it is evident that a very few number of the sample Islamic banks comply with AAOIFI accounting standards related to IAHs reporting.

Furthermore, it is observed that IAHs disclosure level varies from $4 \%$ to $74 \%$. Thus, $\mathrm{Al}$ Baraka Islamic Bank (Bahrain) has the highest IAHs disclosure level (74\% in 2011, 2012 and 2013) followed by Khaleeji Commercial Bank (Bahrain) (68\% in 2014 and 2015), while both Alinma Bank (Saudi Arabia) and Boubyan Bank (Kuwait) have the lowest IAHs disclosure level (4\%). The very wide range between the lowest and the highest IAHs disclosure level can be explained by the variety of standards adopted by those Islamic banks. Thus, both Alinma Bank and Boubyan Bank adopt IAS/IFRS standards, whilst Al Baraka Islamic Bank adopts AAOIFI accounting standards. Moreover, the table shows that the standard deviation value is 0.182 which indicates that there are a large dispersion in IAHs disclosure level between the sample banks and the overall IAHs disclosure level deviate from the expected disclosure level (i.e. more than 50\%).

In all, this result is far below our expectations given that IAHs, as the main source of funds for Islamic banks, have no way of knowing about the management of their funds except the annual report in which relevant IAHs information should be disclosed.

Regarding the disclosure categories included in our disclosure index, Table 2 reports that among the three disclosure categories, Products category has the highest disclosure level which is $31 \%$, whereas IAHs Risk Management has the lowest disclosure level of $14 \%$. 
This means that IAHs are more interested in products disclosure than other disclosures. This makes sense as IAHs may seek above all to maximize profit through investing in profitable products offered by the Islamic bank. As to IAHs Risk Management, the low level of disclosure is explained by the fact that Islamic banks do not disclose in their annual reports the risks or losses related to IAHs, especially to Unrestricted IAHs, which makes their investments very risky. Finally, as for IAHs category, the mean disclosure level is $26 \%$ which is very low. It means that the majority of the sample Islamic banks do not disclose enough information about IAHs disclosure practices.

Our results are similar to those of Srairi (2015) and Sulaiman et al. (2015) who found very low levels of IAHs index (as category of their governance disclosure index) (37\% and $2.68 \%$ respectively). Srairi (2015) noted that the sample banks do not disclose information about the risks and rights of IAHs, investment and asset allocation. Also, he noticed that there was a lack of information on the bases for profits allocation between shareholders and IAHs in the most of the GCC Islamic banks' annual reports. Sulaiman et al. (2015) also found the same results as Srairi (2015) regarding the lack of information on risk management issues in Malaysian Islamic banks' annual reports.

Table 2: Descriptive Statistics

\begin{tabular}{|l|c|c|c|c|c|}
\hline Variable & $\boldsymbol{N}$ & Mean & Std. Dev. & Min & Max \\
\hline IAHS category & 245 & 0.264 & 0.211 & 0.000 & 0.778 \\
\hline PRODUCTS category & 245 & 0.314 & 0.220 & 0.000 & 0.870 \\
\hline RISKMGT category & 245 & 0.144 & 0.216 & 0.000 & 0.667 \\
\hline IAHs Disc level & 245 & 0.280 & 0.182 & 0.038 & 0.736 \\
\hline Level of IAHs funds & 245 & 0.416 & 0.251 & 0.000 & 0.794 \\
\hline AAOIFI & 245 & 0.367 & 0.483 & 0 & 1 \\
\hline ROA & 245 & 0.007 & 0.047 & -0.303 & 0.246 \\
\hline SIZE & 245 & 14.978 & 1.641 & 10.416 & 18.248 \\
\hline GDP growth rate & 245 & 4.836 & 2.294 & 0.500 & 13.400 \\
\hline Inflation rate & 245 & 4.038 & 2.844 & -0.900 & 11.900 \\
\hline
\end{tabular}

N: number of observations; RISK MGT: Risk management; IAHs Disc level: Total IAHs disclosure level

The table also presents some descriptive statistics of our sample. It indicates that the average ratio of total IAHs funds to total assets for the whole sample is around $42 \%$ with 
standard deviation of 0.251 . Furthermore, it is observed that IAHs funds level varies from a minimum value of 0 to maximum of 0.794 . In addition, the descriptive analysis shows that only $37 \%$ of the sampled Islamic banks adopt AAOIFI standards. The majority of the sampled Islamic banks adopt IAS/IFRS and local standards (63\%).

The average profitability measured by ROA is 0.007 . The average size for the sampled banks measured by log total assets is 14.978 . The values of bank size ranges from 10.416 to 18.248 with standard deviation of 1.641 which indicates poor dispersion within the sample. The average GDP growth rate in the sampled countries is $4.836 \%$ with standard deviation of $2.294 \%$. There is a notable disparity in GDP growth rate from one country to the other, with a minimum rate of $0.5 \%$ and a maximum rate of $13.4 \%$. Similarly, the average inflation rate of the sampled countries which measured by Consumer price index over the period from $2011-2015$ is $4.038 \%$ with standard deviation of $2.844 \%$. There is also a huge disparity in the inflation rate with the values ranging from $-0.9 \%$ to $11.9 \%$.

Table 3: The IAHs disclosure level by country

\begin{tabular}{|l|c|c|c|c|}
\hline Country & N & Mean & Min & Max \\
\hline Bahrain & 13 & 0.366 & 0.109 & 0.709 \\
\hline Qatar & 3 & $\mathbf{0 . 5 5 5}$ & 0.540 & 0.574 \\
\hline Jordan & 2 & 0.506 & 0.408 & 0.604 \\
\hline UAE & 4 & 0.353 & 0.264 & 0.426 \\
\hline Saudi Arabia & 4 & 0.120 & 0.038 & 0.215 \\
\hline Kuwait & 5 & 0.137 & 0.042 & 0.196 \\
\hline Turkey & 4 & $\mathbf{0 . 0 9 0}$ & 0.075 & 0.094 \\
\hline Pakistan & 3 & 0.260 & 0.208 & 0.313 \\
\hline Bangladesh & 7 & 0.246 & 0.226 & 0.291 \\
\hline Malaysia & 4 & 0.198 & 0.075 & 0.257 \\
\hline
\end{tabular}

$N$ : number of banks

Table 3 presents the average IAHs disclosure level for each country. It can be observed that Qatar has the highest IAHs disclosure level of $55 \%$ followed by Jordan (51\%), while Turkey, Saudi Arabia and Kuwait have the lowest IAHs disclosure level of 9\%, 12\% and $14 \%$ respectively. This is consistent with the results of Srairi (2015) who found that Qatar 
achieved the first rank in IAHs disclosure category (40\%), whilst Kuwait and Saudi Arabia had the lowest IAHs index scores of $34 \%$ and $36 \%$ respectively.

Figure 1: The IAHs disclosure levels by year and country for the whole sample

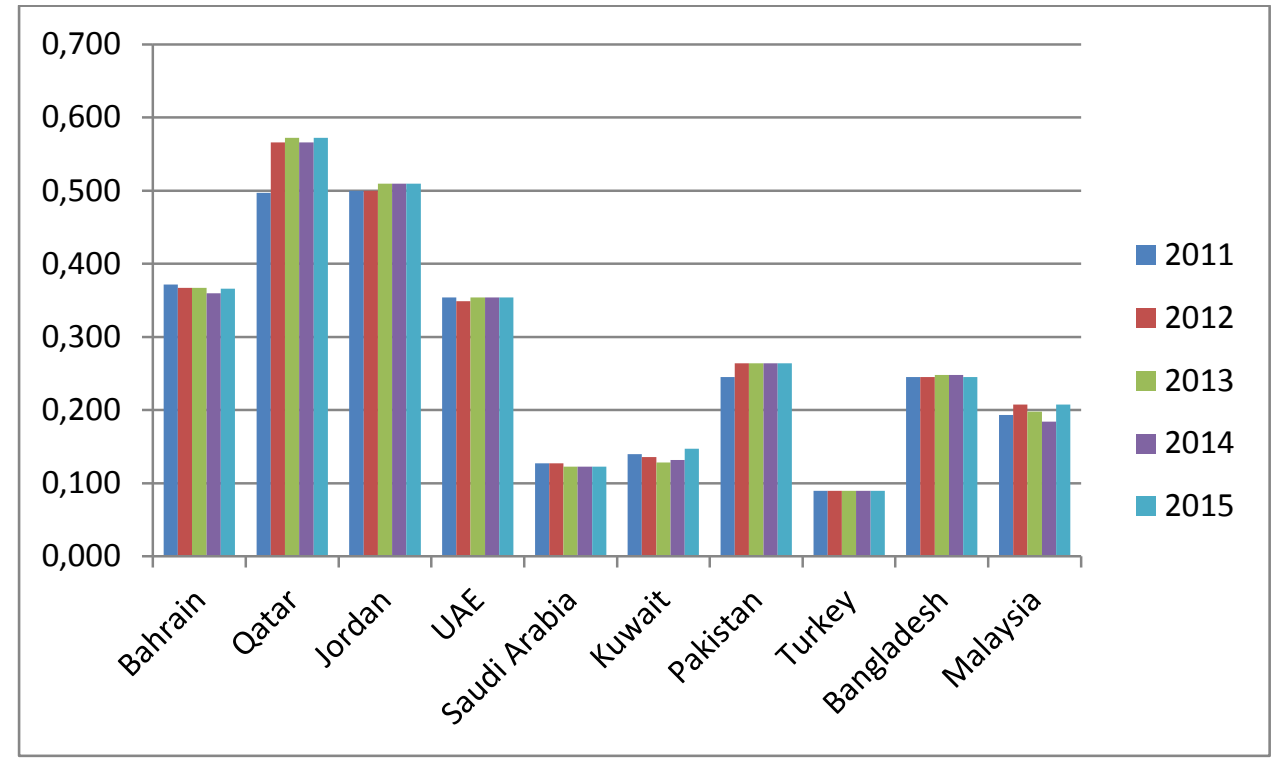

Figure 1 shows the average IAHs disclosure levels over the period 2011-2015 and for each country for the whole sample. The results show insignificant differences between the five years. This means that there is no change in IAHs disclosure levels over the five years. This can be explained by the standard form (i.e. the same form of publication) of the annual reports published between 2011 and 2015. The change in IAHs disclosure levels is only observed between different countries. It can be explained by the variety of standards (AAOIFI standards, IAS/IFRS standards and Local standards) adopting by the sampled Islamic banks. This finding is consistent with El Halaby and Hussainey (2015) who suggested that the change in disclosure levels was based on adopted accounting standards. 
Table 4: The IAHs disclosure level by country and disclosure category

\begin{tabular}{|l|c|c|c|c|c|}
\hline Country & N & IAHS(\%) & PRODUCTS(\%) & RISK MGT(\%) & Total IAH disc(\%) \\
\hline Bahrain & 13 & 33 & 42 & 25 & 37 \\
\hline Qatar & 3 & 40 & 76 & 33 & 55 \\
\hline Jordan & 2 & 64 & 41 & 0 & 51 \\
\hline UAE & 4 & 27 & 50 & 0 & 35 \\
\hline Saudi Arabia & 4 & $\mathbf{7}$ & 20 & $\mathbf{0}$ & 12 \\
\hline Kuwait & 5 & 11 & 19 & 1 & 14 \\
\hline Turkey & 4 & 18 & $\mathbf{0}$ & $\mathbf{0}$ & $\mathbf{9}$ \\
\hline Pakistan & 3 & 20 & 36 & $\mathbf{0}$ & 26 \\
\hline Bangladesh & 7 & 28 & 20 & 29 & 25 \\
\hline Malaysia & 4 & 24 & 17 & 8 & 20 \\
\hline
\end{tabular}

N: number of banks; RISK MGT: Risk management; IAHs Disc level: Total IAHs disclosure level

Table 4 shows that Jordan has the highest disclosure score related to IAHs category (64\%) followed by Qatar and Bahrain (40\% and 33\% respectively), while Saudi Arabia has the lowest disclosure score (7\%). As for Products category, the highest disclosure score is achieved by Qatar (76\%) followed by UAE (50\%) and Bahrain (42\%), whilst Malaysia scores the lowest (17\%). Turkey does not disclose any information about products since the level of disclosure is 0\%. Later, Qatar reaches the highest IAHs disclosure level relating to Risk management category (33\%) followed by Bangladesh $(29 \%)$ and Bahrain (25\%), whereas Malaysia and Kuwait have the lowest disclosure score (8\% and 1\% respectively). For the other countries, the table shows that there is no disclosure of IAHs risk management issues as the disclosure scores are $0 \%$.

In all, although Bahrain is the country where AAOIFI accounting standards have been developed for Islamic financial institutions, it does not rank first in terms of all disclosure categories of the IAHs disclosure index. 
Table 5: The IAHs disclosure level by disclosure subcategory

\begin{tabular}{|l|l|c|}
\hline Categories & Sub-categories & IAH disclosure level(\%) \\
\hline \multirow{4}{*}{ IAHs } & General & 39 \\
\cline { 2 - 3 } & UIAHs & 30 \\
\cline { 2 - 3 } & RIAHs & 10 \\
\cline { 2 - 3 } & Total & 26 \\
\hline \multirow{4}{*}{ Products } & Murabaha & 53 \\
\cline { 2 - 3 } & Mudaraba & 23 \\
\cline { 2 - 3 } & Musharaka & 21 \\
\cline { 2 - 3 } & Total & 31 \\
\hline \multirow{2}{*}{ Risk Mgt* } & & 14 \\
\hline \multicolumn{2}{|c|}{} & 28 \\
\hline
\end{tabular}

UIAHs:Unrestricted IAHs;:RIAHs:Restricted IAHs;RISK MGT*:Risk management (see more details in Table 6);Total IAHs Disc:Total IAHs disclosure level

Table 5 summarizes our main findings in terms of IAHs disclosure level by more details on the categories of the IAHs index (i.e. sub-categories). As indicated in the table, for IAHs category, General disclosure on IAHs has the highest disclosure score, which is around $39 \%$. On the other hand, disclosures on Restricted IAHs have the lowest disclosure score of $10 \%$. As to disclosures on Unrestricted IAHs, the overall disclosure score is around $30 \%$.

Regarding Products category, we find that Murabaha has the highest disclosure score of 53\%, whilst Musharaka scores the lowest (21\%).

Table 6: IAHs Risk Management disclosure index

\begin{tabular}{|l|c|}
\hline Risk Management Disclosure & Total IAHs disclosure(\%) \\
\hline RIAHs RISK Management & 3 \\
\hline UIAHs RISK Management & 24 \\
\hline DCR Management & 16 \\
\hline
\end{tabular}

As shown in Table 6, the IAHs Risk Management disclosure category is classified into three risk management practices that may attract IAHs interest, such as Restricted and Unrestricted IAHs risk management and Displaced Commercial Risk (DCR). Then, it appears that Unrestricted IAHs risk management practices are the most disclosed information of the IAHs risk management index with a mean score of $24 \%$, whilst 
Restricted IAHs risk management practices are the least disclosed information with a mean score of $3 \%$. As for the DCR, it scores only $16 \%$ across the whole sample which indicates a considerable lack of disclosure on whether Islamic banks face the DCR. Further, we find only nine Islamic banks that disclose about the DCR. This is consistent with the results of Abdul Rahman et al. (2013) who found poor disclosure on the DCR by Islamic banks in the MENA region with a mean score of $3 \%$. They noted that only 3 out of 20 Islamic banks disclosed the DCR as one of the risks they face.

Table 7: The IAHs disclosure level by standards

\begin{tabular}{|l|c|c|c|c|}
\hline Standards & $\mathbf{N}$ & Mean & Min & Max \\
\hline AAOIFI & 18 & $\mathbf{0 . 4 1 3}$ & 0.075 & 0.736 \\
\hline Others & 31 & $\mathbf{0 . 2 0 1}$ & 0.038 & 0.434 \\
\hline
\end{tabular}

$N$ : number of banks; Others: Local and IAS/IFRS Standards

Table 7 classifies the IAHs disclosure index into two main groups of Islamic banks namely banks that adopt AAOIFI accounting standards and those that adopt other standards (IAS/IFRS and local standards). Thus, it is evident that Islamic banks adopting AAOIFI standards achieve high IAHs disclosure levels (41\%) compared to those adopting other standards (20\%). This means that Islamic banks applying AAOIFI accounting standards disclose more information about IAHs practices issues than those applying other standards. This result is in line with that of Suandi (2017) who argued that applying accounting standards that do not take into account the specificities of Islamic banks leads to poor disclosures pertaining to Profit Sharing Investment Accounts (PSIAs) and noted that Islamic banks applying AAOIFI accounting standards present more comparable and transparent practices of accounting for PSIAs. This is also due to the fact that, unlike IAS/IFRS standards, the AAOIFI accounting standards may reflect the unique characteristics of Islamic banks (Sarea and Hanefah, 2013).

As the IAHs are considered unique to Islamic banks, those who adopt AAOIFI accounting standards should achieve greater levels of IAHs disclosure. Nevertheless, the IAHs 
disclosure level is still very low $(41 \%)$ as the banks disclosed less than $50 \%$ of the disclosure items required by AAOIFI accounting standards. Then, it is observed that even Islamic banks applying AAOIFI accounting standards are not fully complied with these standards. This result is consistent with that of Al-Baluchi (2006) who found that some Islamic banks in Bahrain were not in full compliance with AAOIFI standards and with low voluntary disclosure levels. Similarly, this result is in line with that of Ajili and Bouri (2017) who found that Islamic banks in the GCC had not fully complied with all the IFRS and AAOIFI disclosure requirements. This can be explained by the fact that AAOIFI has no power to enforce the application of its standards on Islamic banks globally (Karim, 2001; Sarea and Hanefah, 2013). On the other hand, the results of the table above show that Islamic banks adopting other standards (i.e. Local and IAS/IFRS Standards) disclose $20 \%$ of the AAOIFI IAHs disclosure requirements. This indicates that there is a convergence movement towards the AAOIFI standards in these Islamic banks.

To sum up, as a result of our findings mentioned above, it seems obvious that the sampled Islamic banks have poor disclosures for IAHs. Thus, particular attention needs to be paid to IAHs reporting to boost IAHs confidence and avoid massive withdrawal of their funds.

\section{Robustness test}

In order to check the robustness of the results of the IAHs disclosure index, we exclude the category of IAHs Risk Management as it consists only of 3 items, compared to IAHs and products categories (27 and 23 items respectively), which may leads to biased results. Then, we compare the new IAHs disclosure index (without IAHs risk management category) with the previous one. The new IAHs index consists of 50 items classified into two categories which are IAHs and Products. The results indicate that the new IAHs disclosure index is 0.287 (around 29\%) which is almost the same in comparison with the 
previous IAHs disclosure index $(28 \%)$. Thus, we conclude that there is no significant difference between the two indices, which proves the robustness of our results.

\section{Conclusion}

Disclosure of relevant information for IAHs in Islamic banks' annual reports is very important since IAHs, despite their status as the main source of funding for Islamic banks, are not allowed to monitor or interfere in the management of their funds. Thus, they need transparent disclosures to protect their rights and to achieve better decision-making.

In this study, we investigate the extent of IAHs disclosure in the annual reports of 49 fullfledged Islamic banks over the period 2011-2015 and across 10 countries. For this purpose, we developed a specific IAHs disclosure index with three main disclosure categories and 53 items based on AAOIFI accounting standards.

Using manual content analysis, the results revealed that the overall IAHs disclosure level is $28 \%$ which is very low. Indeed, Qatar has the highest IAHs index score of $55 \%$ while Turkey scores the lowest (9\%). It should be noted as well that Products disclosures are the most disclosed category of the IAHs index across the whole sample with a mean score of $31 \%$, whereas the least attention is given to IAHs risk management disclosures which achieved a mean score of $14 \%$. Interestingly, IAHs disclosure category and more especially, disclosures on Unrestricted IAHs have very low levels which are $26 \%$ and $30 \%$ respectively. Therefore, we can say that Islamic banks give less attention to IAHs disclosure practices despite their great importance as providers of funds to Islamic banks.

Moreover, it can be observed that even Islamic banks that adopt AAOIFI accounting standards have not fully complied with AAOIFI disclosure requirements in terms of IAHs reporting. Hence, it is obvious that there are still great gaps between IAHs disclosure requirements and current practices. AAOIFI accounting standards should have been applied by all Islamic banks around the world with special regard to IAHs reporting. Thus, 
both AAOIFI and IASB should increase its efforts to harmonize the accounting practices of Islamic banks in order to achieve higher levels of IAHs disclosure in Islamic banks. Alternatively, regulators bodies in different countries around the world should impose the adoption of AAOIFI accounting standards for all Islamic banks to strengthen disclosure practices for IAHs. In other words, Islamic banks have unique characteristics that differ from their conventional counterparts, especially in the case of investment account holders. In addition, it has been shown that the latter is not treated by IFRS standards but it is taken into account by AAOIFI standards (Grais and Pellegrini, 2006; Hassan et al., 2019a). Thus, regulators should consider the uniqueness of IAHs in Islamic banks and their importance as major stakeholders. As a consequence, they should protect their interest by imposing the application of AAOIFI standards.

Moreover, as suggested in a number of the previous studies (e.g., Archer et al., 1998; Chapra and Ahmed, 2002; Grais and Pellegrini, 2006; Ghayad, 2008; Safieddine, 2009; Hamza, 2016), IAHs should be represented in the board of an Islamic bank to control the behavior of managers and protect their rights.

The unavailability of annual reports in the websites of several Islamic banks across different countries around the world is the main limitation of our study. As a consequence, our study covered only 10 countries and this makes the sample size very small in each country. Thus, the findings reported in the current study cannot be generalized. In spite of that, this study provides new insights on IAHs disclosure practices in Islamic banks. In addition to the content analysis of annual reports, future research may use a questionnaire survey administered to IAHs in measuring the extent of IAHs disclosure in order to better understand the information needs of IAHs. Also, future researchers could examine the new accounting standard FAS 27 "Investment Accounts" (AAOIFI, edition 2015) and replicate our IAHs disclosure index. The latter will be useful in future research on the determinants 
and consequences of IAHs disclosure in Islamic banks. Finally, to extend the sample size, future studies could cover other countries outside the GCC region, MENA, and Southeast Asia as highlighted by Hassan et al., 2019b.

\section{References}

- Accounting and Auditing Organisation for Islamic Financial Institutions (AAOIFI), (2010). “Accounting, Auditing and Governance Standards for Islamic Financial Institutions". AAOIFI, Manama, Bahrain.

- Abdullah, A. , Percy, M. and Stewart, J. , (2015) "Determinants of Voluntary Corporate Governance Disclosure: Evidence from Islamic Banks in the Southeast Asian and the Gulf Cooperation Council Regions", Journal of Contemporary Accounting \& Economics, Vol. 11, Issue 3, pp. 262-279

- Abdullah, A., Percy, M. and Stewart, J. , (2013) "Shari'ah disclosures in Malaysian and Indonesian Islamic banks: The Shari'ah governance system", Journal of Islamic Accounting and Business Research, Vol. 4 Issue 2, pp.100 - 131

- Abdul Rahman, R., Saimi, N. and Lawal, D.B. (2016) "Determinants of ethical identity disclosure in Islamic banks: an analysis of practices in Bahrain and Malaysia”, Jurnal Pengurusan, Vol.46. pp. 13-22

- Abdul Rahman, R. Kighir,A. Oyefeso L. and Abdel Salam, O. (2013) "Risk Management Disclosure Practices of Islamic Banks in the Mena Region: An Empirical Analysis”, Middle East Journal of Scientific Research, Vol. 15 Issue 1, pp.152-160.

- Abdul Rahman, A.R. (2010), "An introduction to Islamic accounting theory and practice", CERT Publications Sdn. Bhd., Kuala Lumpur.

- Ajili, H. and Bouri, A., (2017) "Comparative study between IFRS and AAOIFI disclosure compliance: Evidence from Islamic banks in Gulf Co-operation Council countries", Journal of Financial Reporting and Accounting, Vol. 15 Issue 3, pp.269292

- Al-Baluchi, A. E. A., (2006) 'The Impact of AAOIFI Standards and Other Bank Characteristics on the Level of Voluntary Disclosure in the Annual Reports of Islamic Banks', Ph.D. Thesis, School of Management, University of Surrey. 
- Al-Deehani, T. Karim, R. and Murinde, V. (1999), "The Capital Structure of Islamic Banks under the Contractual Obligations of Profit Sharing", International Journal of Theoretical and Applied Finance. Vol. 2, No.3.

- Alshattarat, W., Atmeh, M. , (2016) "Profit-Sharing Investment Accounts in Islamic Banks or Mutualization, Accounting Perspective", Journal of Financial Reporting and Accounting, Vol. 14 Issue 1, pp. 1-31

- Archer S, Karim RA., Sundararajan V., (2010) "Supervisory, regulation, and capital adequacy implications of profit-sharing investment accounts in Islamic finance", Journal of Islamic Accounting and Business Research, Vol. 1 Issue 1, pp. 10-31

- Archer S, Karim RA. (2009) Profit-sharing investment accounts in Islamic banks: Regulatory problems and possible solutions. Journal of Banking Regulation, Vol.10, Issue 4, pp. 300-306.

- Archer, S. and Karim, R. (2006). "On capital structure, risk sharing and capital adequacy in Islamic Banks", International Journal of Theoretical and Applied Finance, Vol. 9 No. 3, pp. 269-280.

- Archer, S. Karim, R. and Al Deehani, T. (1998), "Financial Contracting, Governance Structure and the Accounting Regulation of Islamic Banks: An analysis of Agency Theory and Transaction Cost of Economics", Journal of Management and Governance, Vol.2, Issue 2, pp. 149-170.

- Barrett, M.E., (1976) "Financial Reporting Practices: Disclosure and Comprehensiveness in an International Setting", Journal of Accounting Research, Vol. 14, Issue 1, pp. 10-26.

- Baydoun, N. and Willett, R. (2000), "Islamic Corporate Reports", Abacus, Vol. 36, Issue 1, 2000, pp. 71-90.

- Beattie, V., B. McInnes, S. Fearnley., (2004). “A Methodology for Analyzing and Evaluating Narratives in Annual Reports: A Comprehensive Descriptive Profile and Metrics for Disclosure Quality Attributes", Accounting Forum, Vol. 28 Issue 3, pp.205236.

- Berelson, B. (1952). “Content analysis in communication research”, New York, Free Press Content analysis in communication research, $220 \mathrm{pp}$.

- Botosan, C. A. (1997). "Disclosure level and the cost of equity capital», The Accounting review, Vol. 72, Issue 3, pp. 323-349. 
- Cerf, A. R. (1961). “Corporate Reporting and Investment Decisions”, Berkeley: The University of California Press.

- Chapra, M. U. and Ahmed, H. (2002), “Corporate Governance in Islamic Financial Institutions”, Islamic Development Bank, Islamic Research and Training Institute, Periodical Document No. 6.

- Cooke, T., (1989a), "Voluntary corporate disclosure by Swedish companies", Journal of International Financial Management and Accounting, Vo11, Issue 2, pp. 171-95.

- Cooke, T. E. (1989b), "Disclosure in the Corporate Annual Reports of Swedish Companies", Accounting \& Business Research, Vol. 19, Issue 74, pp.113-224.

- El-Halaby, S., Hussainey, K. and Al-Maghzom, A., (2017), "Multi-Disclosures in the Context of National Cultures: Evidence from Islamic Banks", Advances in Accounting Behavioral Research, Vol. 20, pp. 117 - 157.

- El-Halaby, S. and Hussainey, K., (2016),"Determinants of compliance with AAOIFI standards by Islamic banks", International Journal of Islamic and Middle Eastern Finance and Management, Vol. 9 Issue 1 pp. 1-21

- El-Halaby, S. (2015), Accountability Practices of Islamic Banks: A Stakeholders' Perspective, Doctoral Thesis in Accounting, United Kingdom, Plymouth University

- Elhamma, A. (2015), La comptabilité des produits financiers islamiques : Normes AAOIFI vs. IFRS, Revue de Management et de Stratégie, Vol.1, Issue 2, pp.10-22.

- Farag, H., Mallin,C. et Ow-Yong,K., (2014),"Corporate social responsibility and financial performance in Islamic banks.", Journal of Economic Behavior \& Organization, Vol. 103, pp. S21-S38

- Farook, S., Hassan, M. K. and Lanis, R. (2011).’Determinants of corporate social responsibility disclosure: The case of Islamic banks", Journal of Islamic Accounting and Business Research, Vol. 2, Issue 2, pp.114 - 141.

- Febianto, I. (2012),"Adapting Risk Management for Profit and Loss Sharing Financing of Islamic Banks," Modern Economy, Vol. 3, Issue 1, pp. 73-80.

- Ghayad R. (2008) "Corporate governance and the global performance of Islamic banks", Humanomics, Vol.24, Issue 3, pp.207-216

- Grais, W. and Pellegrini, M. (2006), "Corporate Governance and Stakeholders' Financial Interests in Institutions Offering Islamic Financial Services”, World Bank Policy Research Working Paper 4053. 
- Gray, R., Kouhy, R. and Lavers, S. (1995b), "Methodological themes: constructing a research database of social and environmental reporting by UK companies", Accounting, Auditing and Accountability Journal, Vol. 8 , Issue 2, pp. 78-101.

- Hamza, H. (2016), "Does investment deposit return in Islamic banks reflect PLS principle?" Borsa Istanbul Review, Vol 16, Issue 1, pp. 32-42

- Haniffa, R. and Hudaib, M. (2007), "Exploring the ethical identity of Islamic banks via communication in annual reports", Journal of Business Ethics, Vol. 76, pp. 97-116.

- Hassan, A. and Harahap, S.S., (2010) "Exploring corporate social responsibility disclosure: the case of Islamic banks", International Journal of Islamic and Middle Eastern Finance and Management, Vol. 3, Issue 3, pp.203 - 227

- Hassan, M.K. (2012),"A disclosure index to measure the extent of corporate governance reporting by UAE listed corporations", Journal of Financial Reporting and Accounting, Vol. 10, Issue 1, pp. 4 -33.

- Hassan, M.K., Aliyu, S., Huda, M. and Rashid, M. (2019a), "A survey on Islamic Finance and accounting standards”, Borsa Istanbul Review, Vol. 19, Supp 1, pp. S1S13.

- Hassan, M. K., Aliyu, S., and Hussain, M. (2019b). A contemporary review of Islamic finance and accounting Literature. The Singapore Economic Review. S0217590819420013 http://doi.org/10.1142/S0217590819420013.

- Hassan, O. and Marston, C. (2010). "Disclosure Measurement in the Empirical Accounting Literature - A Review Article». Available at SSRN: https://ssrn.com/abstract=1640598.

- Healy, P. M. and Palepu, K. G. (2001), "Information asymmetry, corporate disclosure, and the capital markets: A review of the empirical disclosure literature", Journal of Accounting and Economics, Vol. 31, pp. 405-440.

- Hussainey, K. (2004), “A study of the Ability of (partially) Automated Disclosure Scores to Explain The Information Content of Annual Report Narratives for Future Earnings", Doctoral Thesis in Accounting, Manchester, University of Manchester.

- Hussan, S.M., Sulaiman, M. (2016), "Between International Financial Reporting Standards (IFRSS) and Financial Accounting Standards (FASS): The debate continues», International Journal of Economics, Management and Accounting, Vol 24, Issue 1, pp. 107-123 
- IFSB 4 (2007), "Disclosures to promote transparency and market discipline for institutions offering Islamic financial services (Excluding Islamic Insurance (Takaful) Institutions And Islamic Mutual Funds)" Islamic Financial Services Board, Kuala Lumpur.

- IMF Working Paper No. WP/02/192, (2002), "Islamic Financial Institutions and Products in the Global Financial System", International Monetary Fund.

- Karim, R. A. A., (2001). "International accounting harmonization, banking regulation, and Islamic banks". The International Journal of Accounting, Vol 36, pp.169-193.

- Krippendorff, K. (2004a), "Content Analysis: An Introduction to Its Methodology" (2nd Ed.). Thousand Oaks, CA: Sage

- Krippendorff, K. (2004b). "Reliability in Content Analysis: Some Common Misconceptions and Recommendations", Human Communication Research, Vol. 30, Issue 3, pp.411-433

- Lahrech, N. Lahrech, A. and Boulaksil, Y., (2014),"Transparency and performance in Islamic banking", International Journal of Islamic and Middle Eastern Finance and Management, Vol. 7, Issue 1, pp. $61-88$

- Maali, B. and Napier, C. (2010), "Accounting, religion and organizational culture: the creation of Jordan Islamic Bank", Journal of Islamic Accounting \& Business Research, Vol. 1, Issue 2. pp.169-193

- Maali, B., Casson, P., Napier, C. (2006), "Social reporting by Islamic banks", Abacus, Vol. 42, Issue 2, pp. 266-289.

- Magalhaes, R., and Al-Saad, S. (2013). Corporate governance in Islamic financial institutions: the issues surrounding unrestricted investment account holders. Corporate Governance: The International Journal of Business in Society, Vol. 13, Issue1, pp. 3957.

- Marston, L and Shrives, J., (1991) "The Use of Disclosure Indices in Accounting Research: A Review Article”, British Accounting Review, Vol. 25, pp. 195-210

- Milne, M. and Adler, R. (1999), "Exploring the reliability of social and environmental disclosures content analysis", Accounting, Auditing and Accountability Journal, Vol. 12, Issue.2, pp. 237-256

- Neuendorf, K. A. (2002). The content analysis guidebook. Thousand Oaks, CA: Sage. 
- Safieddine, A., (2009), "Islamic Financial Institutions and Corporate Governance: New Insights for Agency Theory", Corporate Governance: An International Review, Vol.17, Issue 2, pp.142-158

- Sarea, A.M., Hanefah, M.M. (2013) "The need of accounting standards for Islamic financial institutions: evidence from AAOIFI", Journal of Islamic Accounting and Business Research, Vol. 4 Issue 1, pp.64-76

- Sarea, A. M., (2012) "The Level of Compliance with AAOIFI Accounting Standards: Evidence from Bahrain", International Management Review, Vol 8, Issue 2, pp. 27- 32.

- Sori, Z.M.,(2017) "Accounting Conceptual Frameworks: MASB vs. AAOIFI" Available at SSRN: http://dx.doi.org/10.2139/ssrn.2900666

- Srairi, S. (2015), “Corporate Governance Disclosure Practices and Performance of Islamic Banks in GCC Countries”, Journal of Islamic Finance, Vol. 4, № 2, pp.1-17

- Steenkamp, N. and Northcott, D. (2007)," Content Analysis in Accounting Research: the Practical Challenges", Australian Accounting Review, Vol 17, Issue 3, pp.12-25

- Suandi, AB. (2017) "Classification of profit-sharing investment accounts: A survey of financial statements of Islamic banks in Asia", International Journal of Islamic and Middle Eastern Finance and Management, Vol. 10 Issue 3, pp.351-370

- Sulaiman, M., Majid, N.A. and Arifin, N.M. (2015). "Corporate governance of Islamic financial institutions in Malaysia”, Asian Journal of Business and Accounting, Vol. 8, Issue 1, pp. 65-93

- Sundararajan, V. (2013), "Risk characteristics of Islamic products: Implications for risk measurement and supervision", in Karim, R. A. A. \& Archer, S. (Ed.), Islamic Finance: The Regulatory Challenge, Wiley, Singapore, pp. 49-75.

- Taktak, N. B. (2011), "The nature of smoothing returns practices: the case of Islamic banks", Journal of Islamic Accounting and Business Research, Vol 2, pp.142-152.

- Taktak, N.B., Zouari, B.S. and Boudriga, A., (2010), "Do Islamic banks use loan loss provisions to smooth their results?" Journal of Islamic Accounting and Business Research, Vol.1, Issue2, pp. 114-127.

- Ullah, H. (2013), “Compliance of AAOIFI Guidelines in General Presentation and Disclosure in the Financial Statements of Islamic Banks in Bangladesh", International Journal of Social Science Research, Vol 1, Issue 2, pp. 111-123

- Van Greuning, H. and Iqbal, Z. (2008), "Risk Analysis for Islamic Banks", The World Bank, Washington, DC. 
- Vinnicombe, T. (2012), “A study of compliance with AAOIFI accounting standards by Islamic banks in Bahrain", Journal of Islamic Accounting and Business Research, Vol. 3, Issue 2, pp. 78-98.

- Weber, R. P. (1990). Basic content analysis (2nd Ed.). Newbury Park, CA: Sage. 


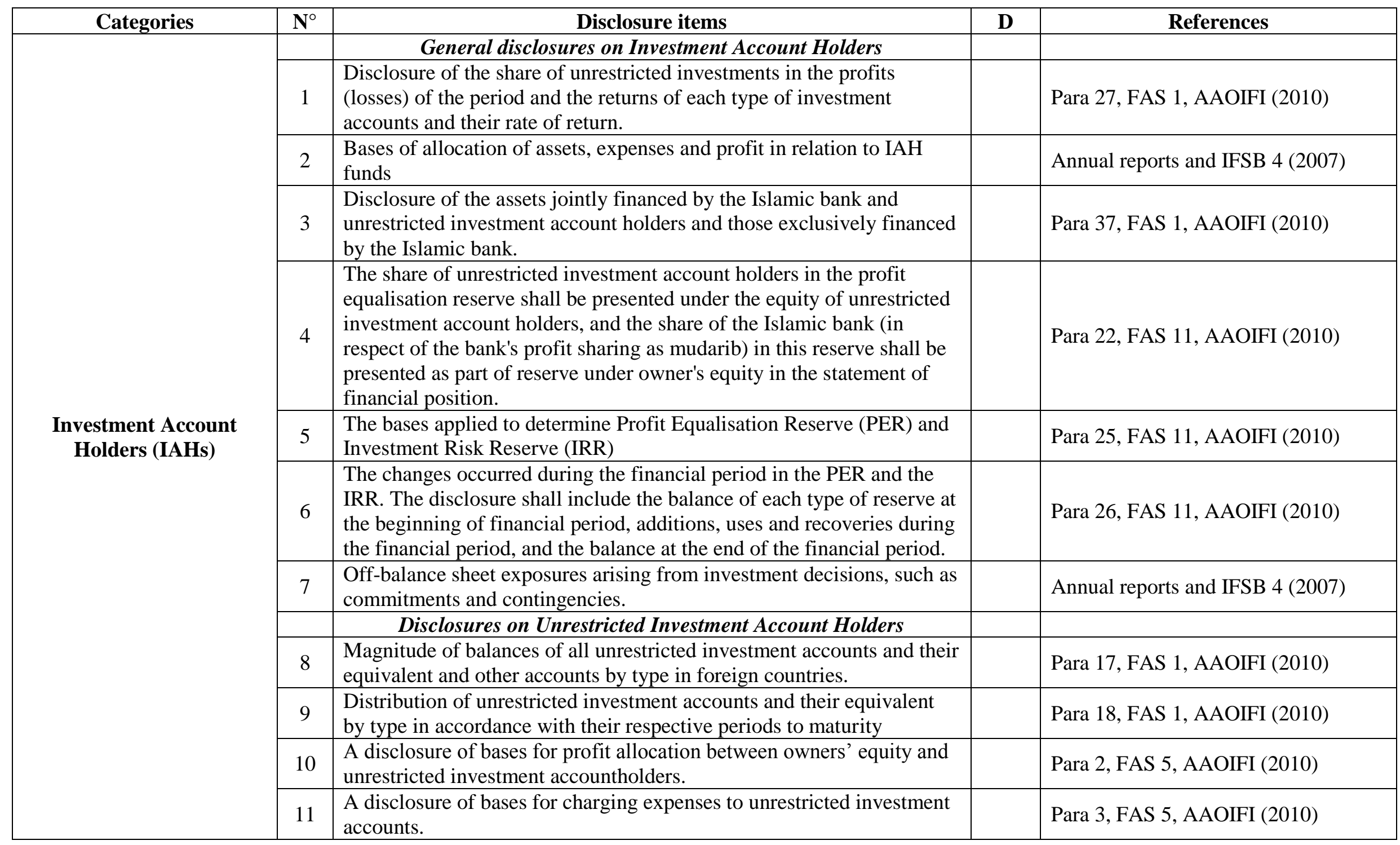




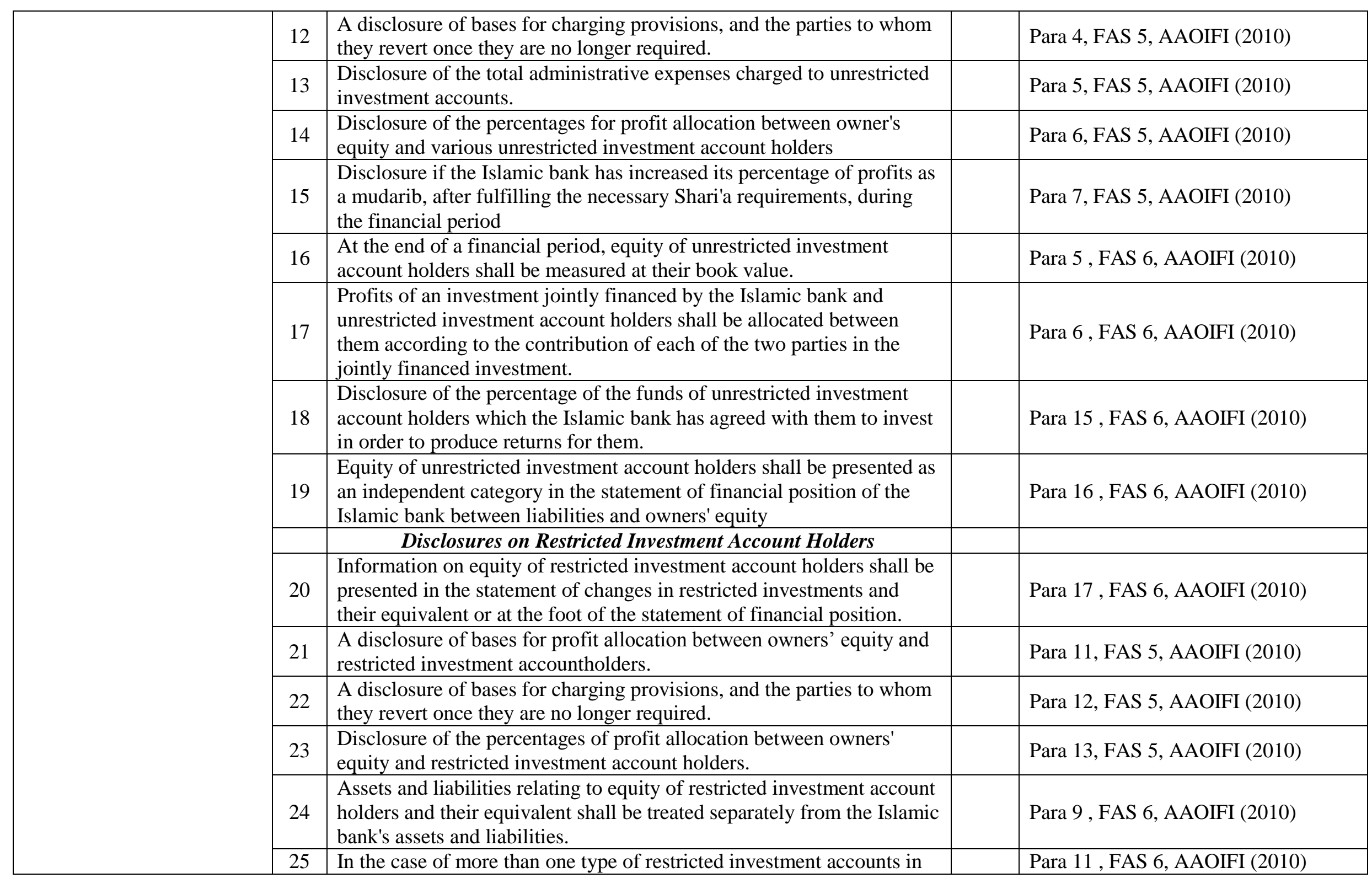




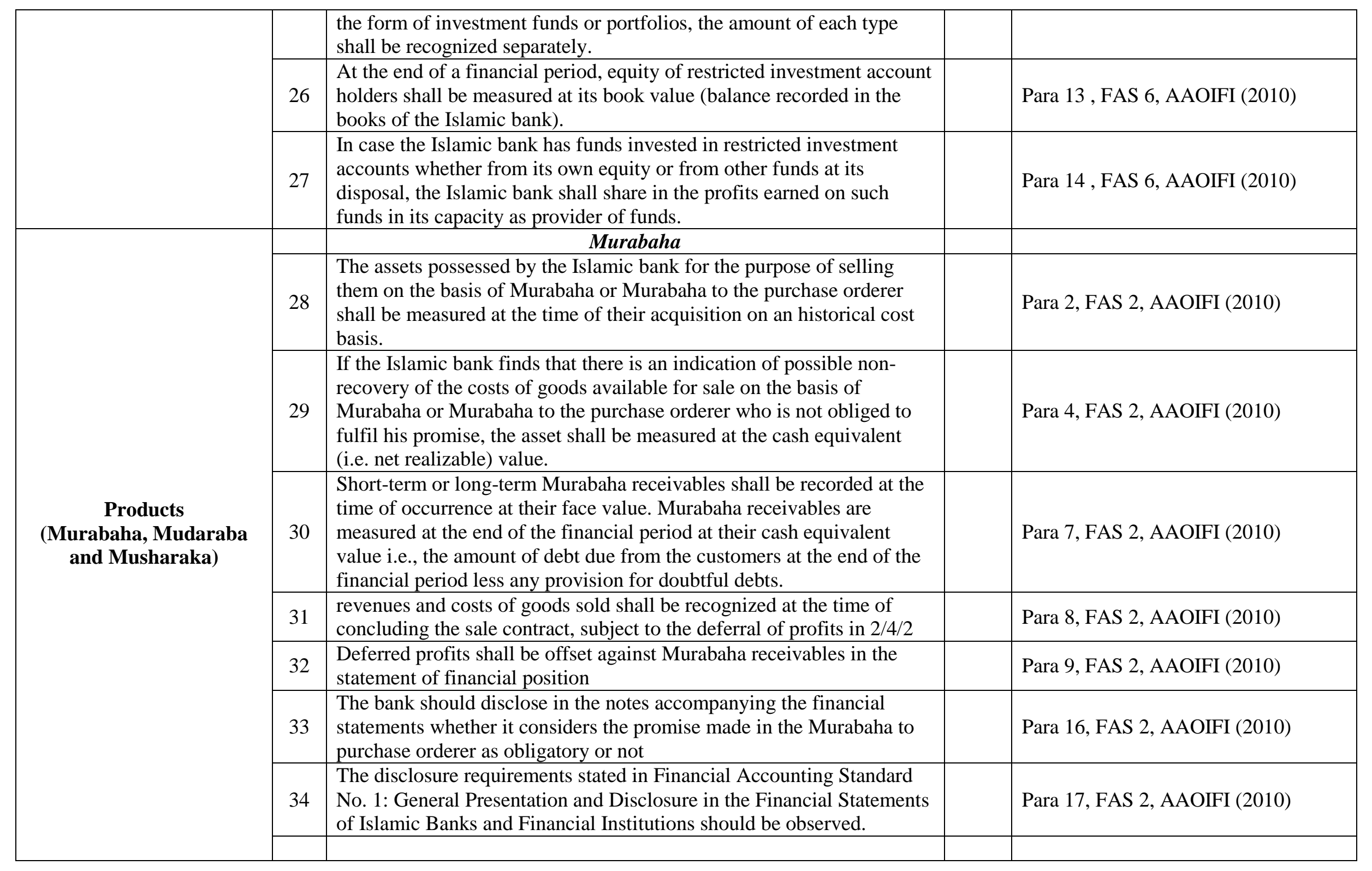




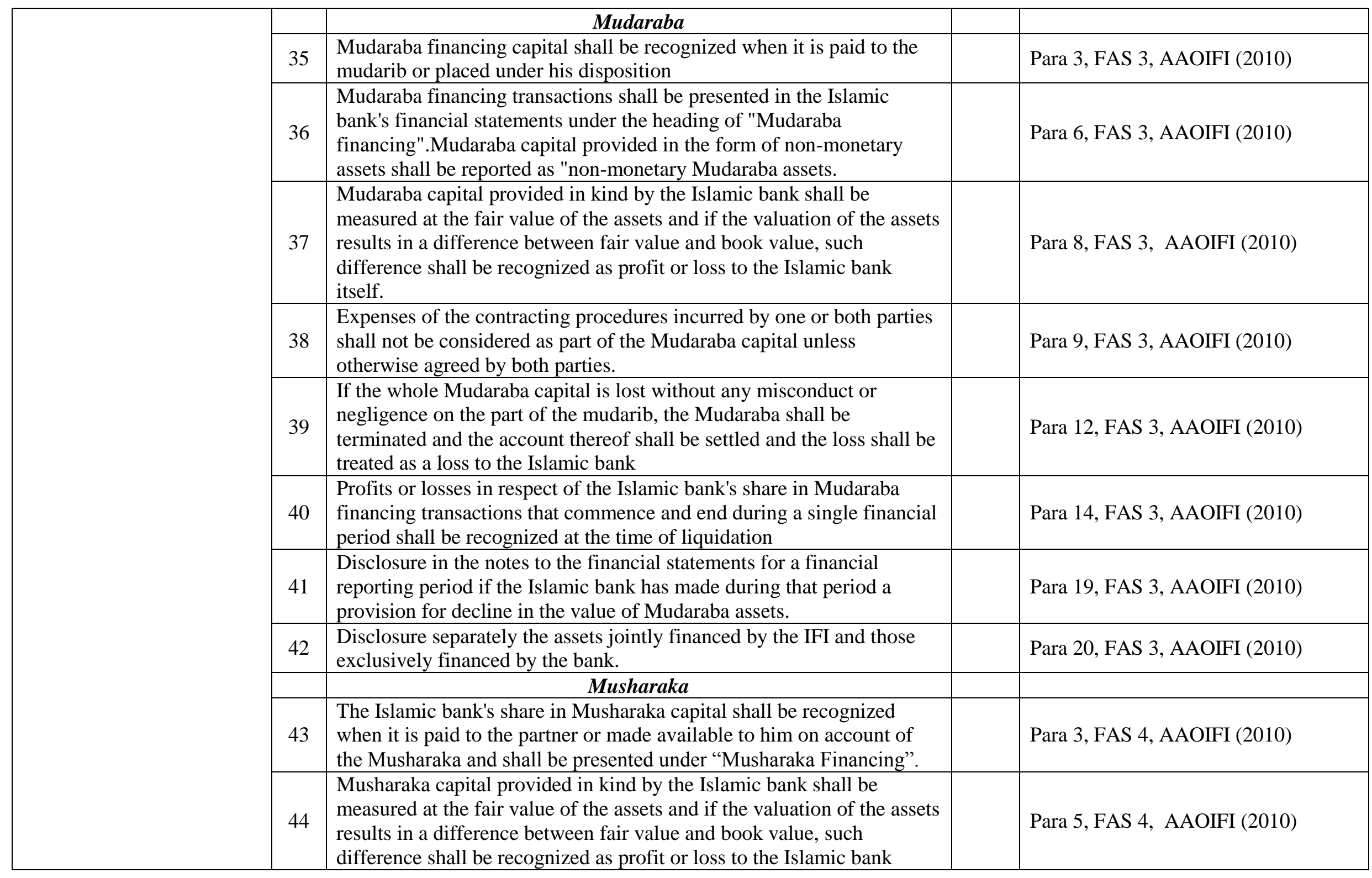




\begin{tabular}{|c|c|c|c|}
\hline & & itself. & \\
\hline & 45 & $\begin{array}{l}\text { Expenses of the contracting procedures incurred by one or both parties } \\
\text { shall not be considered as part of the Musharaka capital unless } \\
\text { otherwise agreed by both parties. }\end{array}$ & Para 6, FAS 4, AAOIFI (2010) \\
\hline & 46 & $\begin{array}{l}\text { The Islamic bank's share in the constant Musharaka capital shall be } \\
\text { measured at the end of the financial period at historical cost }\end{array}$ & Para 7,FAS 4, AAOIFI (2010) \\
\hline & 47 & $\begin{array}{l}\text { The Islamic bank's share in the diminishing Musharaka shall be } \\
\text { measured at the end of a financial period at historical cost after } \\
\text { deducting the historical cost of any share transferred to the } \\
\text { partner(such transfer being by means of a sale at fair value). The } \\
\text { difference between historical cost and fair value shall be recognized as } \\
\text { profit or loss in the Islamic bank's income statement. }\end{array}$ & Para 8,FAS 4, AAOIFI (2010) \\
\hline & 48 & $\begin{array}{l}\text { The Islamic bank's share of profits for any period, resulting from } \\
\text { partial or final settlement between the Islamic bank and the partner, } \\
\text { shall be recognized in its accounts for that period of the extent that the } \\
\text { profits are being distributed; the Islamic bank's share of losses for any } \\
\text { period shall be recognized in its accounts for that period to the extent } \\
\text { that such losses are being deducted from its share of the Musharaka } \\
\text { capital. }\end{array}$ & Para 12,FAS 4, AAOIFI (2010) \\
\hline & 49 & $\begin{array}{l}\text { Disclosure in the notes to the financial statements for a financial } \\
\text { reporting period if the Islamic bank has made during that period a } \\
\text { provision for a loss of its capital in Musharaka financing transactions }\end{array}$ & Para 17,FAS 4, AAOIFI (2010) \\
\hline & 50 & $\begin{array}{l}\text { Disclosure separately the assets jointly financed by the IFI and those } \\
\text { exclusively financed by the bank }\end{array}$ & Para 18, FAS 4, AAOIFI (2010) \\
\hline \multirow{4}{*}{ IAHs Risk management } & 51 & $\begin{array}{l}\text { Risk management practices in relation to investments of restricted } \\
\text { investments account holders' funds. }\end{array}$ & App. GSIFI No 6, AAOIFI (2010) \\
\hline & 52 & $\begin{array}{l}\text { Appropriate risk management measures in relation to fiduciary } \\
\text { obligations of Mudarib (Unrestricted investments account holders) }\end{array}$ & App. GSIFI No 6, AAOIFI (2010) \\
\hline & 53 & Displaced commercial Risk Management & Annual reports \\
\hline & & Total score & \\
\hline
\end{tabular}

D: 1 if the item is disclosed in the annual report and 0 if it is not disclosed 
Appendix 2: List of AAOIFI Standards using in the construction of the IAHs disclosure index

\begin{tabular}{|l|l|}
\hline $\begin{array}{l}\text { AAOIFI } \\
\text { Standards }\end{array}$ & \multicolumn{1}{c|}{ Description } \\
\hline FAS 1 & $\begin{array}{l}\text { General Presentation and Disclosure in the Financial Statements of Islamic Banks } \\
\text { and Financial Institutions }\end{array}$ \\
\hline FAS 2 & Murabaha and Murabaha to the Purchase Orderer \\
\hline FAS 3 & Mudaraba Financing \\
\hline FAS 4 & Musharaka Financing \\
\hline FAS 5 & $\begin{array}{l}\text { Disclosure of Bases for Profit Allocation between Owners' Equity and Investment } \\
\text { Account Holders }\end{array}$ \\
\hline FAS 6 & Equity of Investment Account Holders and Their Equivalent \\
\hline FAS 11 & Provisions and Reserves \\
\hline GSIFI 6 & Statement on Governance Principles for Islamic Financial Institutions \\
\hline
\end{tabular}

Source: AAOIFI standards 2010 edition 